\title{
RELATIONSHIP BETWEEN VERBAL LANGUAGE AND SYM- BOLIC PLAY - A CASE STUDY
}

\author{
DENISE SEGAL, M.A. (SPEECH PATHOLOGY) (WITWATERSRAND) \\ Department Speech Pathology and Audiology, University of the Witwatersrand, \\ Johannesburg.
}

\section{SUMMARY}

The linguistic ability and play of a language-impaired child were analysed to determine whether a breakdown in symbolic play occurs together with a language deficit. Observation of play was conducted at the child's nursery school (unstructured situation) and in a situation designed to elicit specific play behaviours (structured situation). Imaginative play and its concomitants - affect, mood variability, concentration, aggression and interaction - were rated along descriptive scales, while each individual play unit was scored for organization of behaviour. Syntactic, semantic and phonological aspects of language were recorded during free play and analyzed within a syntactic framework. The normal developmental sequence provided the baseline of comparison for both language and play. Results indicated a developmental lag in play and a linguistic deviation from the normal pattern, which supported the possibility of a general representational deficit. A method for incorporating symbolic play into a language programme was suggested and the necessity for normative studies in this area was stressed.

\section{OPSOMMING}

Die linguistiese vermoë en spel van 'n taalgestremde kind is ontleed om vas te stel of 'n versteuring in simboliese spel gelyk met 'n taaltekort plaasvind, al dan nie. Waarneming van spel het by die kind se kleuterskool plaasgevind (ongestruktuurde situasie) en ook in 'n situasie beraam om spesifieke speelgedrag te ontlok (gestruktueerde situasie). Verbeeldingsryke spel en die konkomitante verskynsels - gevoelsinhoud, wisselvalligheid van stemming, konsentrasie, aggressie, en aksie en reaksie - is volgens beskrywende maatstawe beordeel, terwyl elke adsonderlike speleenheid vir organisasie van gedrag opgeteken is. Sintaktiese, semantiese en fonologiese aspekte van taal is gedurende vry spel aangeteken en binne 'n sintaktiese raamwerk geanaliseer. Die normale ontwikkelingsvolgorde is gebruik as die basis van vergelyking vir sowel taal as spel. 'n Ontwikkelingsvertraging in spel en 'n linguistiese afwyking van die normale is deur die resultate aangedui, wat die moontlikheid ondersteun van 'n algemene weergewende tekort. 'n Metode om simboliese spel in 'n taalprogram te integreer is voorgestel en die noodsaaklikheid vir normatiewe studies in dié gebied beklemtoon.

It is generally agreed upon by researchers that language and cognition are correlated although the nature of the relationship is controversial. Recent investigations $\mathrm{s}^{2}, 3,4,21,31,32$ have tended to support Piaget's hypothesis ${ }^{24}$ that language is based in prior cognitive growth. This suggests that a linguistic breakdown may be a reflection of an underlying cognitive disturbance thereby providing a conceptual framework within which to view diagnosis of, and therapy for, the language-impaired child..$^{1,21}$

Definitions and classifications of play are numerous and variable according to theoretical orientation but the viewpoint adopted in the present investigation is that of Piaget. ${ }^{25} \mathrm{He}$ theorized ${ }^{24}$ that children

Die Suid-Afrikaanse Tydskrif vir Kommunikasieafwykings, Vol. 27, 1980 
aged two to four years develop a general representational ability which manifests in all symbolic systems, namely, deferred imitation, imagery, drawing, dreaming, symbolic play and language. He defined symbolic play as ". . . the deformation and subordination of reality to the desires of the self". ${ }^{25}$ Lunzer $^{17}$ considered it to be the natural medium of behaviour and of intellectual growth at that period which coincides with speech development. Although the cause-effect relationship is undetermined, ${ }^{12}, 15,17$ language and symbolic play are believed to share a common cognitive base and to function similarly as 'signifiers' to an absent content. While language enables man ... to represent objects and situations in their absence . . . (p. 207) ${ }^{17}$ symbolic play allows the child to use one object, action or event, to represent another object, action or event. ${ }^{10}, 19,28$

It is thought that language at first accompanies play until the child's naming of an object emancipates word from object. ${ }^{7}$ With increased play complexity and the substitution of play names for real names at about three years of age, the child is able to plan an activity verbally. ${ }^{7}, 18$ Since the actions involved in play resemble the significant content, they are believed to be more easily acquired than wordmeanings which are arbitrary. ${ }^{1,24}$ This suggests that in some children a linguistic deficit may also present with a breakdown in symbolic play. Piaget (p. 338) ${ }^{25}$ described play as ... an exercise of action schemes ... in which assimilation predominates over accommodation. Thus the child utilizes and incorporates an aspect of the environment into himself rather than imitating and adapting his own body to the social milieu. In 1951 Piaget drew up a classification scheme comprising practice play, symbolic play and games with rules, each class characteristic of a particular developmental stage - sensori-motor, representational and concrete operational respectively. During the sensori-motor stages II-V (from 2 to 28 months), the child's actions are exercised for pleasure alone. The genesis of the symbolic function occurs at about 18 months of age (Sub-stage IV), with a subsequent developmental progression both in the organization of symbolic play behaviours, and in the degree of representational ability that they reflect. $17,24,31$

Piaget's scales, although theoretical and not intended for clinical usage, have been adapted by researchers such as Lunzer ${ }^{17}$ and Bass et $\mathrm{al}^{1}$ for use in both clinical and natural settings. Bass et al stressed that in truly symbolic behaviour, the child is aware of the distortion of reality whereby the action occurs out of context. Initially, the action rather than the object is the symbol and can be performed with objects inadequate to fulfil the goal (e.g. using a stick in a representation of eating), or in the absence of any objects (e.g. simulating eating with no external aids). At this stage, the child is able to perform these actions only upon himself, and is not able to attribute them to others until the Representational Stage has been reached.

The Representational Stage comprises three substages, each including 
different types of behaviour, according to their symbolic structure. During Substage I, the child is able to project his own actions (type IA), and then his imitated action patterns (type IB) onto new objects. Substage II, involves representation by simply identifying one object with another, eg. picking up a stick and saying, "This can be a broom" (type 2A) and subsequently, by using bodily actions to assume another identity (type 2B). The child's ability to utilize individual objects symbolically within an integrated framework (type 3A) is apparent from three to four years of age. The value of symbolism in play subsequently diminishes in that it becomes differentiated into games with rules. Thus while these substages and classes constitute an evolutionary continuum with no clear delineations ${ }^{15}, 16$ they do allow for the study of the child's cognition through the observable mode of symbolic play. This is felt to be particularly appropriate for the language-impaired child where cognitive investigation through the linguistic medium would inevitably be unrepresentative of his true performance.

Comparatively few studies have investigated the relationship between language and symbolic play, but the symbolic function has been shown to be impaired in linguistically deviant children. $1,15,21,22$ In addition, Luria and Yudovich, ${ }^{18}$ and Vygotskaia ${ }^{7}$ found progress in symbolic play as a result of speech improvement. However, further research is necessitated. The investigation by Lovell, Hoyle and Siddall ${ }^{15}$ considered only duration of play behaviour which Lunzer found to be an unreliable measure, whereas Bass et $\mathrm{al}^{1}$ utilized a structured play situation only, thereby ignoring crucial aspects which have been found to be related to play. These comprise affect during play, concentration and aggression, as well as interaction and co-operation with both peers and adults.

It is controversial which aspects of play actually involve symbolic or abstract thought. El'Konin ${ }^{7}$ considered only dramatic play, the substitution of an imaginary situation to satisfy the child's needs. Other investigators $^{17,30}$ have added constructive play whereby objects are manipulated in order to create. It was this latter viewpoint that was adopted by the present investigator.

Play, like language, is learnt in relation to ongoing meaningful activities. ${ }^{13}$ The writer thus set out to study play .... in the overall context of the individual and social actions of the child. (p. 339) ${ }^{25}$ The child's continuous interaction with his environment as an essential aspect of play has been emphasized since his spontaneous . . . direct collision. . . with reality (p. 228) ${ }^{7}$ enables him to assimilate reality to his limited cognitive schema. In accordance with Singer, ${ }^{33}$ it is believed that certain defensive or conflict-reducing behaviours may also participate in this process. Interaction with, and observation of adults, has been similarly emphasized in the development of play. This is believed to facilitate separation of an activity from an object, its generalization to new objects, and progressive abstraction of usage. 
Freyberg ${ }^{8}$ also argued that the adult model serves as the catalyst for the development of latent skills which are basically within the child's capabilities, despite lacks in experience or cognition. Whereas the parent initially directs the child's behaviour by verbal instruction, this is later internalized by the child.

On the basis of foregoing findings, the aim of the present study was to analyse and to describe qualitatively the symbolic play and linguistic ability of a language-impaired child. More specifically, this study was designed to determine whether a linguistic breakdown would manifest with a corresponding breakdown in symbolic play.

\section{METHODOLOGY}

\section{AIMS}

1. To describe qualitatively and to analyze the symbolic play and linguistic ability of a language-impaired child.

2. On the basis of the above, to determine whether a symbolic breakdown will co-occur with a language impairment.

3. If (2) above is supported, to determine whether the nature of the breakdown, that is, delay versus impairment, at the level of play corresponds with that at the language level (namely, impairment).

4. To determine whether play performance of this particular child differs in a structured versus an unstructured situation.

5. On the basis of the above findings, to devise a therapy programme for this child incorporating symbolic play within a linguistic framework.

\section{SUBJECT}

One male child (S) aged 3 years 8 months was selected as subject. He was the youngest of three children and had been diagnosed by a qualified speech therapist from the Speech and Hearing Clinic at the University of the Witwatersrand, Johannesubrg, as presenting with an expressive language-impairment. $S$ fulfilled the following criteria:

1. Chronological Age - S's chronological age fell within the range of that reported in normal development for a fully established linguistic system $\left(3 \frac{1}{2}-4\right.$ years) and heightened symbolism in play (2-4 years). ${ }^{17,24}$

2. Mental Age - Due to S's inattention and lack of co-operation, a traditional IQ measure could not be established However, $\mathrm{S}$ was assessed by his speech therapist to be of average intelligence according to his performance on non-verbal tasks.

3. S had no physical or primary emotional disability.

4. S had hearing within normal limits.

5. At the commencement of observation, $S$ had been attending a nursery school (mornings only) for five months, thereby ensuring that he had adjusted to, and had become familiar with, the physical and social environment.

6. Previous speech therapy could not be controlled for. For a year 
prior to this study, $S$ had attended a play group for languageimpaired children three times a week, while simultaneously receiving individual speech therapy twice a week at the Speech and Hearing Clinic of the University of the Witwatersrand. However, while the added stimulation with regard to language and play as well as experience with play materials would influence the child's performance, it would work against the proposed hypothesis of a deficit in play occurring together with a language deficit.

GENERAL PROCEDURE

1. Language:

(a) Syntax and Semantics - A sample of the child's spontaneous oral language was elicited during his regular speech therapy period. Play materials included toys and action pictures which have been found to facilitate speech in three and four-year olds. The entire session was tape recorded using a reel-to-reel tape recorder. S's regular therapist conducted the session with the experimenter (E) observing behind a one-way mirror. The therapist and $E$ together transcribed the utterances.

(b) Phonology - This was included only to ensure differentiation between a syntactic error and one which was phonologically based, for example, omission of copula versus omission of phoneme [s]. The Phonetic Inventory Test was administered by both the therapist and $\mathrm{E}$.

2. Play:

(a) Unstructured Play Situation - E visited the nursery school to familiarize herself with the environment and routine. Play materials included all the indoor and out-door equipment present. Children were not encouraged into conversation with her, and any questions were answered 'tersely but pleasantly'. This allowed her to become part of the situation as an 'object' offering nothing in return for a child's advances as would an assistant. This ensured that $E$ would exert minimal influence on the child's activity. ${ }^{15}$

E observed the child during free play for twenty ten-minute periods which were randomly scattered over ten days. The number of ratings was sufficient to eliminate such variables as the individual's feelings at the time and fluctuations in performance, ${ }^{17}$ while brief periods minimized the influence of fatigue. An interval of at least five minutes was allowed between each observation period. E transcribed the child's overt expressions, play behaviours, interactions and verbalizations.

A random sample of one in every five of the play sessions was simultaneously observed but independently transcribed and rated by a second, similarly experienced observer.

(b) Structured Play Situation - This was carried out during one of the child's speech therapy periods after completion of observa- 
tions in the unstructured situation. This prevented experience with play materials and examples of their symbolic usage from influencing the child's performance in the unstructured situation. The entire session which lasted 20 minutes was recorded on a reel-to-reel videotape. Instructions were conveyed with the aid of linguistic and gestural cues and by means of example, in order to minimize the possible influence of receptive difficulties.

RATING SCALES AND ANALYSIS OF DATA:

1. Language:

(a) Syntax and Semantics - The child's language was analyzed in relation to the context and his ongoing activities.

While a semantic analysis would appear to be more applicable in relation to cognitive assessment, a syntactic analysis was preferred on the basis of the view of Crystal et $\mathrm{al}^{6}$ that no semantic theory has been worked out sufficiently for descriptive studies of any general validity to have taken place. A standardized syntactic analysis allowed for the establishment of a quantitative language level as well as affording qualitative analysis. This was necessary in order to confirm the diagnosis of language-impairment and to ascertain whether delay occurred together with impairment.

It is felt that if the interaction between language and symbolic play was being considered at a 'microscopic' (rather than a 'macroscopic') level, a semantic and pragmatic analysis would be more appropriate. This would involve analysing the functional language that occurs together with a particular type of play activity, for example, language that serves to extend the play activity as opposed to language that describes the ongoing activity. Contrarily, the present study aimed to determine a language level, a play level, and only subsequently to establish whether similarities exist between these two behaviours in this particular child. this constitutes a 'macroscopic' or 'surface level' analysis. Thus, semantics and pragmatics were included only to differentiate a semantically-based from a syntacticallybased error, as well as to exemplify unintelligible utterances by considering their intent within the play context.

Analysis included Development Sentence Scoring (DSS) and Development Sentence Types (DST) comprising, Developmental Sentence Analysis (DSA) devised by Lee. ${ }^{13}$ From the corpus, the final fifty intelligible and consecutive complete sentences (with noun and verb in subject-predicate relationship) were selected for DSS analysis. Repeated, stereotyped and imitated utterances were excluded. It was agreed by the therapist (who was 'blind' to the aims of the study) and $E$ that $S$ had acclimitized to the situation, and that his optimal performance was thereby included in the sample. The 68 pre-sentence 
formulations from the corpus were included in a DST analysis. In addition, all S's utterances in which the target was a complete sentence (179) were analysed qualitatively in terms of linguistic trends as well as use and diversity of base structure and transformational rules.

(b) Phonology - The Phonetic Inventory Test was analysed by $\mathrm{E}$ together with a member of the Phonetics and Linguistics Department at the University of the Witwatersrand.

2. Play:

(a) Unstructured Play Situation - Play behaviour was rated along the dimension of imaginativeness, affect, mood variability, concentration, aggression and interaction with peers and adults, devised by Singer. ${ }^{33}$ In accordance with Lunzer's ${ }^{17}$ view that constructive play is a pretence or abstraction from reality, this type of play was included in the rating for imaginativeness. This dimension and those for affect and concentration each received one overall score for the most frequent behaviour within each ten-minute period. A score was assigned for each and every interactive and co-operative behaviour displayed since it was often impossible to assign only one descriptive term which would do justice to the diversity of these behaviours within any ten-minute period.

The scale for aggression measured direct overt aggression as opposed to that manifest in make-believe play. Here, intensity rather than frequency of behaviour was considered. It was felt that an intense aggressive attack against a peer, even if momentary, could hinder future interactions and therefore, social play. The rating from 1-4 on the Aggression Scale was altered to $1-5$ to comply with scoring on the other scales. A low score of 1 was positive, indicating no aggression, while a high score of 5 was negative, describing a great deal of aggression. For all other scales the reverse occurred in that a score of 1 was the negative side of the scale, for example, indicating low imaginativeness in play.

In addition to the above, each separate play unit was rated on a 9-point index for the Organization of Play Behaviours devised by Lunzer. ${ }^{17}$ This comprises two subscales - Adaptiveness in the Use of Play Materials which measures the child's treatment of the play materials, and Integration of Behaviour which concerns the complexity of the play behaviour itself. This scale yielded validity and reliability scores of 0,73 and 0,75 respectively. Significant interscorer correlations of 0,$92 ; 0,97 ; 0,85$ and 0,90 (p 0,05) were obtained by means of the Pearson ProductMoment Correlation Coefficient.

(b) Structured Play Situation - Play was rated on a modification of Lunzer's scale devised, in an unpublished Masters Dissertation, by Bass, Brown and Redmond. ${ }^{1}$ This measured symbolic play 
behaviours at the substages, and of the type described by Piaget. $^{24}$

\section{RESULTS}

The dearth of normative studies yielding quantitative data necessitated a largely qualitative analysis. For both language and play the normal developmental sequence served as the baseline for comparison. Chronology, as well as the child's present developmental stage allowed any delay in, or deviation from the norm to be noted.

1. Language: $S$ obtained a DSS score of 5,44 which falls below the tenth percentile for his chronological age. ${ }^{13,14}$ His language usage was comparable to that of a child aged 3 years 1 month, indicating a delay of seven months.

DST analysis demonstrated that $S$ used the earlier acquired verb phrase (VP) more frequently than the noun phrase (NP). Although $S$ did combine noun and modifier to constitute two-word NP's, his VP constructions were more advanced, being three, four or five words in length. This indicated that $S$ was in a transition stage between pre-sentence formulation and consistent sentence stage.

Qualitative analysis revealed a delay in language development as well as a deviation from the normal sequence (impairment). The base structure rule $(\mathrm{S} \rightarrow \mathrm{NP}+\mathrm{VP})$ was not fully established, diversity of structural type and frequency of usage were limited, while application of transformational rules was not consistently correct.

2.1 Play Behaviour:

(a) Imaginative Play as Rated on the Scale Devised by Singer. ${ }^{33}$ From Figure 1 it is evident that S's most frequently occurring play behaviour was either extremely unimaginative and stimulus-bound (a score of 1) or it included a few pretend elements with little originality or organization (a score of 2).

(b) Organization of Play Behaviours as Rated on the Scale Devised by Lunzer. ${ }^{17}$ Figure 2 reveals that $S$ most frequently used play materials '. . . in a manner recalling the play of infants' $57 \%$ of the time). Cognizance was not taken of their physical or representational properties, and the integration of play behaviours was minimal with little achieved (a composite score of 2). S's play behaviour fell predominantly ( $89,9 \%$ of the time) within scores 2-6 which has been equated with/Piaget's 'Practice Play'. He obtained a score of 7, comparable to the rudimentary stages of Piaget's 'Symbolic Play' (scores 7-10) only $10,1 \%$ of the time.

Thus, on the basis of his performance, it appears as though $\mathrm{S}$ is functioning slightly below the range for his age level although still conforming with the normal developmental pattern. The peak of symbolic play at two-to-four years of age ${ }^{17,24}$ was not apparent from his performance in the unstructured situation. 


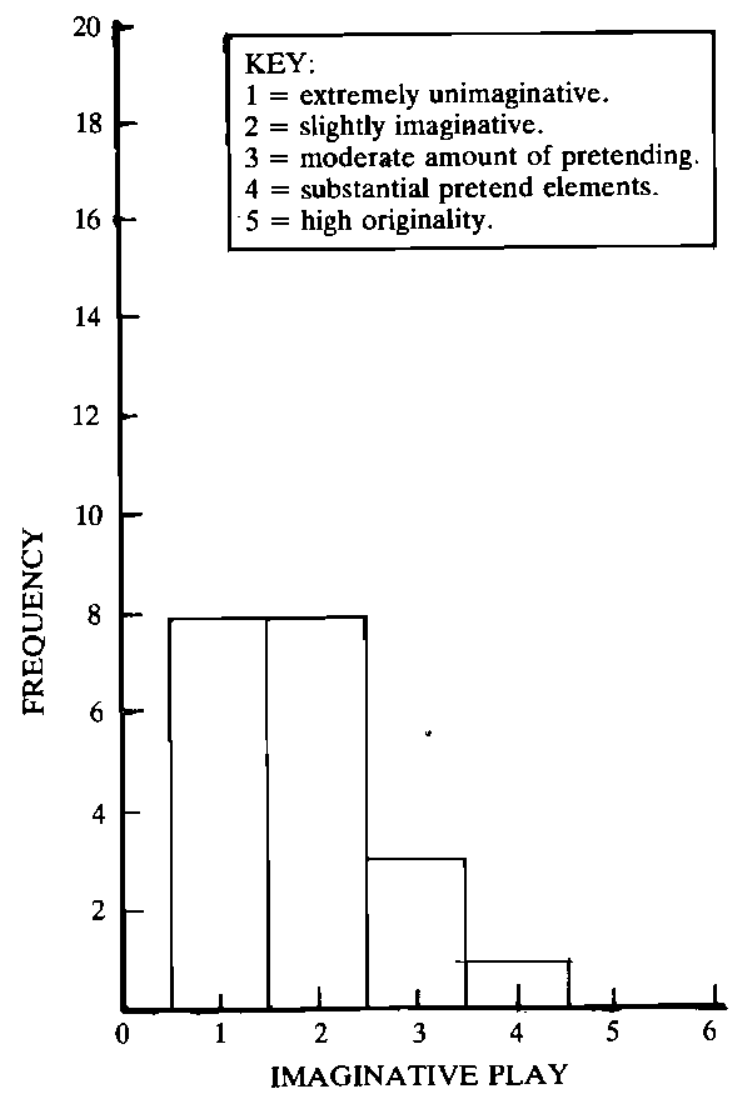

Figure 1. Frequency of occurrence of imaginative elements in play.

(c) Performance in Structured Play Situation - This was included to determine whether $S$ would be able to perform these activities when presented with appropriate stimuli for their elicitation. A qualitative analysis of S's performance demonstrated his ability to carry out activities equivalent to all stages except Stage IIIB. At all stages, the highest score attained $\left(\mathbf{I}_{3}\right)$, described integration of a number of separate behaviours within the framework of a fairly complex task. For example, in Representational Substage I, type IA, he put his hand into the box and lifted 'food' from the 'bowl' to the doll's mouth.

The highest score achieved for Adaptiveness in the Use of Play Materials was A3, that is, the material was used with regard to its properties but in an obvious way. For example, in Representational Substage $\mathrm{II}$, type $2 \mathrm{~A}$, he built a tower and a train by placing blocks along a vertical and horizontal plane respectively. In one example only, he received higher scores of A5 for highly 


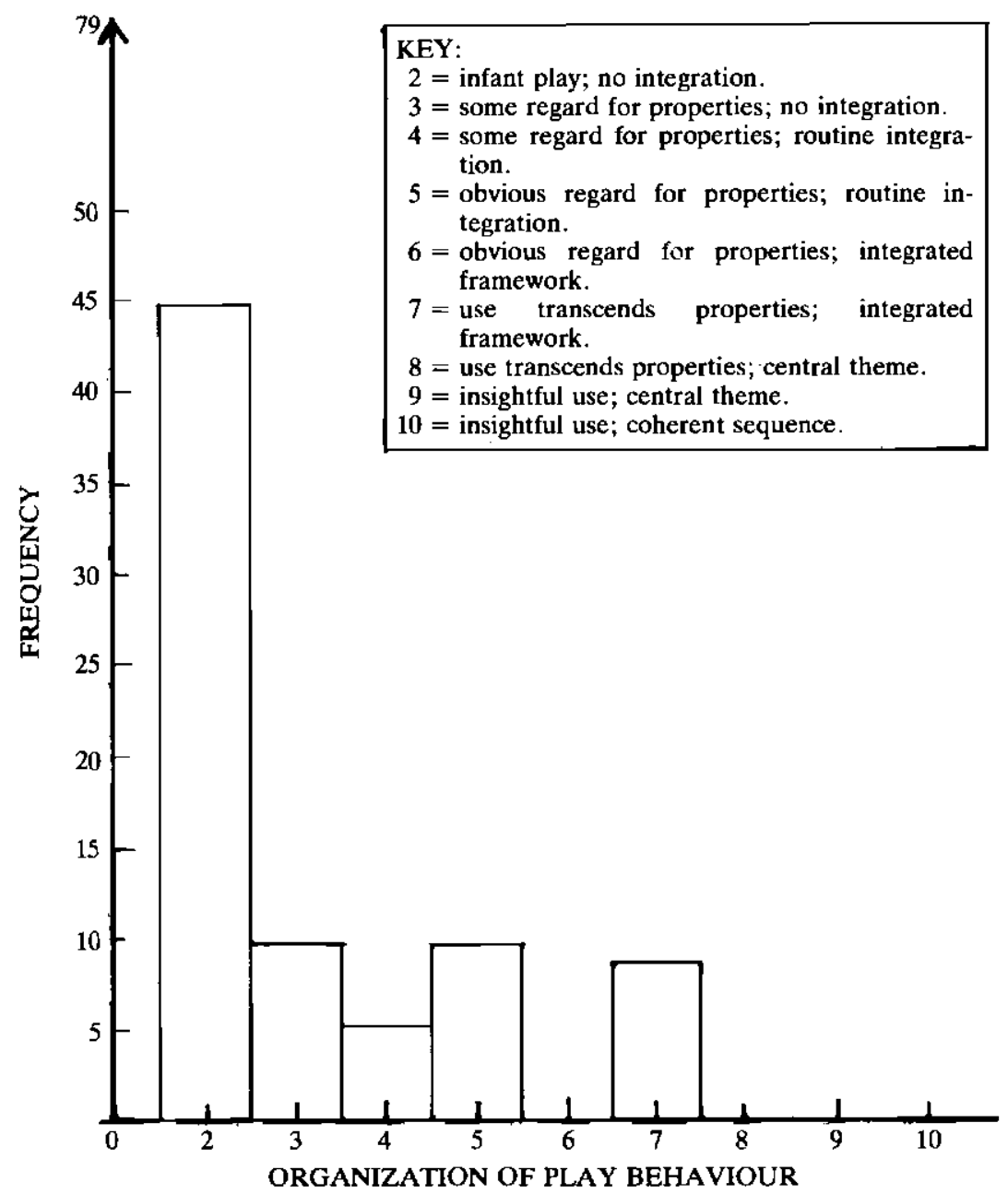

Figure 2. Frequency ratings of categories of play organization.

insightful usage of material and $\mathrm{I}_{4}$ for the elaboration of a single theme, when he displayed types $2 \mathrm{~A}$ and $2 \mathrm{~B}$ concurrently (not included in scale by Bass et al). Here he represented án 'alarm clock' by combining two objects, a bubble-blower and a hair roller, while simultaneously producing a ringing sound.

Thus, S's performance at all stages, though inconsistent, was more advanced than that displayed in the nursery school.

\subsection{Associated Play Concomitants: (Refer Fig. 3)}

(a) Affect - From Figure $3 A$ it can be seen that $\mathrm{S}$ scored 2 predominantly for affect, descriptive of only mild pleasure and interest accompanying 'desultory manipulation' of play ma-

The South African Journal of Communication Disorders, Vol. 27, 1980 

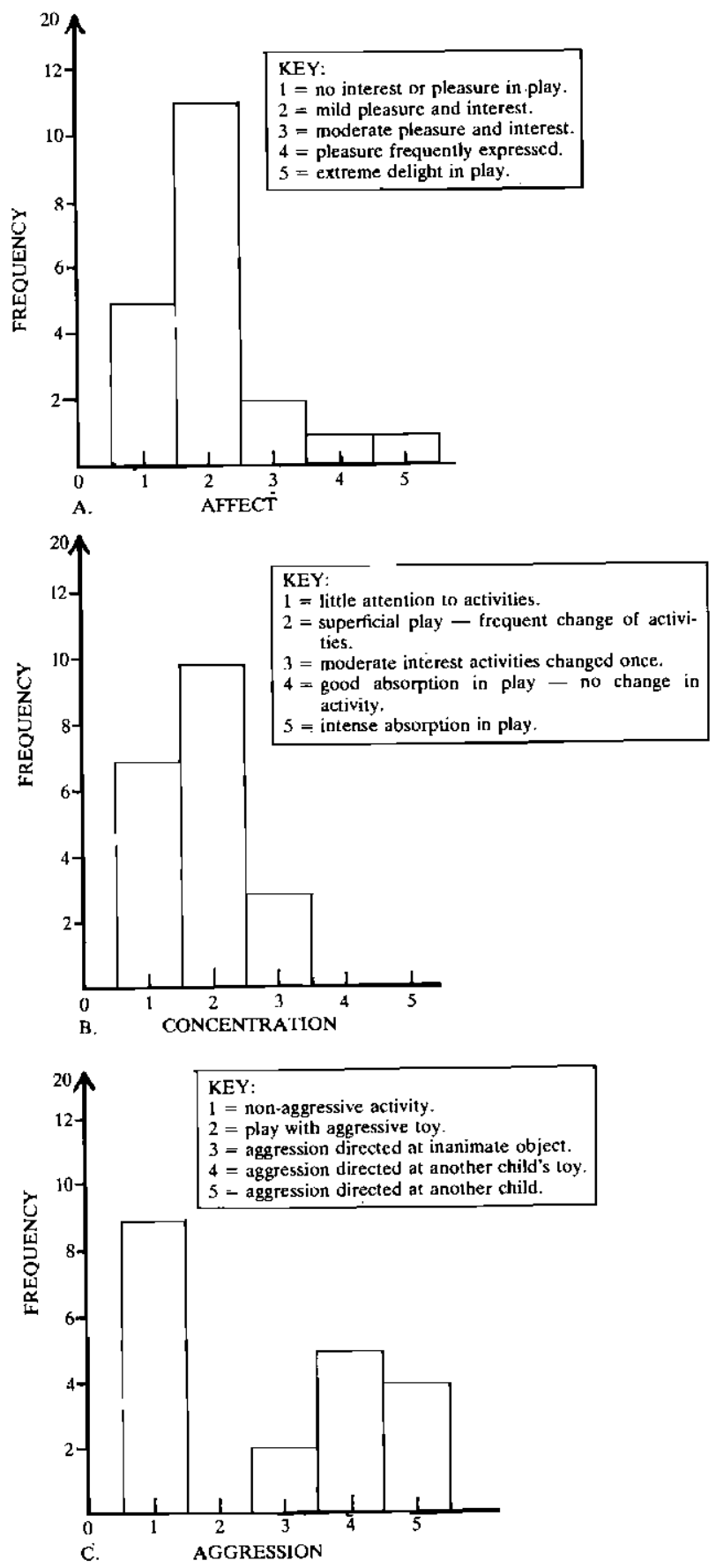

Figure 3. Frequency ratings of categories of affect, concentration and aggression.

Die Suid-Afrikaanse Tydskrif vir Kommunikasieafwykings, Vol. 27, 1980 
terials. He did enjoy himself in the play situation (scores 3, 4 and 5) although this occurred infrequently. A Pearson ProductMoment Correlation Coefficient demonstrated a significant relationship $(r=0,48 ; p 0,05)$ between play and affect. It has been argued that the child should display positive affect if the play in which he is engaged is inherently rewarding. 8,33

(b) Concentration: - From Figure $3 B$ it is evident that $\mathrm{S}$ engaged predominantly ( $50 \%$ of the time) in 'superficial play', altering toys and activities frequently while looking around the room, staring passively, talking to the teacher, or wandering aimlessly. A further $35 \%$ of the time he displayed 'Hyperactivity with no real interaction with play material'. A significant correlation $(r=0,46 ; p 0,05)$ was found between imaginative play and concentration. The child's generation of complex, interesting games, should create sufficient satisfaction for prolonged involvement.

(c) Aggression - It is apparent from Figure $3 C$ that $\mathrm{S}$ engaged predominantly in non-aggressive activities (a score of 1 occurred $45 \%$ of the time). However, an additional $45 \%$ was involved with directing a threat or physical attack against another child (scores 4 and 5 combined). No significant correlation was found between play and aggression. Figure 4 demonstrates that $\mathrm{S}$ sought adult company more often than that of his peers. Interaction with his peers varied from an apparent lack of trust to interact, resulting in avoidance of contact (a score of 1) to actively seeking their company (a score of 4 ).

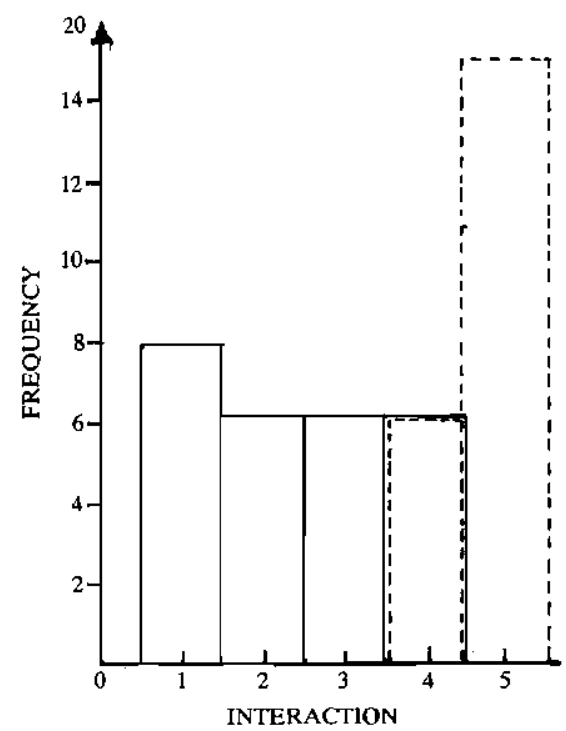

$-=$ interaction with peers

$\ldots=$ interaction with adults

KEY:

Interaction with Peers

$1=$ ayoids contact.

$2=$ reluctant interaction.

$3=$ ready participation with peers.

$4=$ at ease with pecrs.

$5=$ initiates and maintains peer relationships.

Interaction with Aduits

$1=$ avoids contact.

$2=$ reluctant interaction

$3=$ ready participation with peers;

$4=$ at ease with peers.

$5=$ initiates and maintains peer relationship.

Figure 4. Frequency ratings of categories of interactive behaviour.

The South African Journal of Communication Disorders, Vol. 27, 1980 
(d) Interaction - A correlation coefficient between interaction (with peers and adults) and imaginative play could not be determined due to the differing number of scores rated along the two dimensions. However, imaginative play has been viewed as a vehicle to enhance social development.

\section{GENERAL DISCUSSION}

The results demonstrated a linguistic deviation from the norm and a developmental delay in symbolic play, with sensori-motor activity predominating. Thus, in relation to the aims of this study, $S$ manifested with a breakdown in both representational functions but the nature of the deficit differed.

The contention that the sensori-motor child is 'egocentric' in his overt actions while the pre-operational child is 'egocentric' in his representations, ${ }^{23}$ lends support to the finding that $S$ is in a transition period from sensori-motor to symbolic activity. The symbolic function, rather than appearing in its final form, can be seen to build gradually upon sensori-motor achievements. $3,17,26,31$

The play protocols affirm that this child's use of language was 'amorphous', similar to that of a two-year old. ${ }^{18}$ It was almost exclusively an adjunct to direct ongoing activity, for example, 'I riding bike!'. In addition, $S$ made use of verbalizations to indicate his needs and as a tool to gain another person's attention.

On the few occasions that $S$ played symbolically in the unstructured situation it was the accompanying language, rather than the behavioural organization per se, that demonstrated its symbolism. This is contrary to the finding of Lovell, Hoyle and Siddall ${ }^{15}$ that normal three and four-year olds gain so much satisfaction out of their self-created symbols in play that language is secondarily important. It is possible that S's inability to organize his play behaviours necessitated the use of language to explain its symbolism.

Only once, when he used a block of wood as a 'gun' to 'shoot' the gardener, did $\mathrm{S}$ demonstrate a substantial amount of pretending (a score of 4). His total involvement in this play activity was demonstrated by his frowning (suggesting anxiety) when the gardener fell down feigning injury, and by his 'seeking protection' behind an observer when the gardener 'aimed' the 'gun' at him.

This seems to suggest that $S$ has the 'competence' with regard to using play materials to transcend their immediate properties. However, performance would reflect this competence under ideal conditions only. ${ }^{5}$ In addition, variables such as the influence of television, suggest that this might be an imitative rather than a creative activity. ${ }^{33}$ $S$ engaged predominantly in 'sensori-motor activity characterized by the mere pleasure of mastering reality'. His coincident verbalizations such as 'I riding bike!' were bound to his overt activity. If he had referred to the bicycle as a space-ship, for example, clear transcendence of the immediate situation would have been demonstrated.

Die Suid-Afrikaanse Tydskrif vir Kommunikasieafwykings, Vol. 27, 1980 
S's awareness of the 'double function' of objects and actions, (p. 191) and the ability to ascribe these actions to others as opposed to performing them only on himself, was apparent in his few symbolic activities. He rolled a 'snake' from dough and used it symbolically, warning the teacher that it is 'Gonna bite you!' (Representational Stage - Types $1 \mathrm{~A}$ and $1 \mathrm{~B}$ ). S also utilized language to symbolically identify one object with another, as when he picked up sand, threw it into the air and called it 'fire'. However, this cannot be considered as evidence of Substage II since $\mathrm{S}$ interposed physical action between himself and the represented object. As occurs in Substage I, the 'psychological distance' (p. 328) ${ }^{36}$ between the symbolizer and the symbolized was minimal.

S's performance was found to be more advanced in the structured situation as compared with the unstructured setting. This is felt to be important in devising a therapy programme since both the child's potential and his performance should be taken into consideration. It is possible that restricting stimulus materials enhances awareness of novel symbolic applications to the play materials. ${ }^{17}$ However, according to Piaget $^{24}$ who placed Representational Substage III as occurring from age three, $S$ is still functioning below his age level. In addition, only delay from the normal developmental sequence was evident contrary to impairment found for language development.

The consideration of play within a cognitive-affective framework ${ }^{33}$ would account for S's maximal positive affect accompanying sensorimotor as opposed to symbolic behaviour. This model dictates that novel material, within the child's capacity for mastery, will yield interest, alertness and positive emotional reaction. As was evident from S's scores for Organization of Behaviour (Fig. 2), he engaged most frequently in sensori-motor activity.

Since no cause-effect relationship has been determined, it is possible that improved concentration might result in improved imaginative play. In accordance with Freyberg's ${ }^{8}$ suggestion, the present investigator feels that the two correlates may be a unitary dimension, the very nature of imaginative play implying the ability to concentrate.

The present findings for aggression accord with those of Singer. ${ }^{33}$ Freyberg ${ }^{8}$ did find however, that increased role-play behaviour results in decreased fighting.

Socialization with peers was often imitative and $\mathrm{S}$ seemed unable to initiate his own plan of action. He would play alone in their vicinity and subsequently emulate their behaviours particularly if these had been approved by an adult. The development of the symbolic function within the context of imitation as well as the apparent satisfaction $S$ found in activities with adults, are both pertinent issues.

Hyperactivity, distractibility and perseveration, all evident in S's performance, have been found in' association with languageimpairment. ${ }^{34},{ }^{35}$ While the exact relationship between these behavioural manifestations, language and play is as yet undetermined, the 
present findings demonstrated a positive correlation between concentration and imaginative play. Thus, a therapy programme including symbolic play within a linguistic framework would necessarily be incorporating concentration whether directly or indirectly.

\section{CLINICAL IMPLICATIONS}

While a subjective, case study analysis does not allow for generalization of findings to other language-impaired children, it does exemplify aspects of diagnosis and therapy for these children. It is suggested that diagnosis of the child with a language difficulty should include an analysis of his level of play. This affords a non-verbal assessment of his cognitive abilities and general level of symbolic functioning as well as providing for therapeutic direction.

For the child whose receptive language appears to be intact, the structured play situation can be utilized. This allows for a rapid assessment (about 20 minutes per child) involving clinical presentation of tasks graded developmentally. However, since verbal instructions are inherent in its design, it is unsuitable for the child with severe receptive language impairment or for the profoundly deaf child. It is suggested that these latter children be observed in an unstructured setting, either at home or at nursery school and rated along a scale such as that devised by Lunzer. This is time-consuming but it will facilitate differential diagnosis with regard to the child's general level of symbolic functioning.

It is felt that language therapy should be carried out in relation to the child's total cognitive functioning. Whether cognition can be taught is controversial, but materials and activities which are high relative to the child's present level of mastery should be provided in order to challenge his intellectual growth. ${ }^{11}$ Thus, as with regard to his language, so his play must be adapted to the child's unique stage of symbolic usage.

The present writer proposed two ways in which symbolic play can be useful in language therapy:

1. For the child who is using only one-three word utterances - Since the child learns language in relation to his ongoing activities as he interacts with the environment, parents should be encouraged to verbalize their own and the child's actions to allow for word-action association. From the naming of real objects, the child should progress to reproducing the same action using realistic toys and then 'junk' material, following the developmental sequence. Daily activities can be re-enacted in 'pretend' play, for example, acting out a situation of 'going shopping' after the child's return from such an outing. At a later stage, the outing can be played out prior to its occurrence in real life.

Increased play complexity involves progressive 'decentration' of the action from the child's own body, and complexity both in the use of the play material and in the behaviour (or behavioural 
sequence) itself. With increased complexity so the time spent in the activity will be increased, thereby encouraging longer periods of concentration. In addition, involvement in the play activity will lead to positive affect during play, which in turn, will motivate further play. Aggression can also be expressed within the play situation rather than being directed outward.

2. For the child who has acquired sufficient syntax - It is proposed that symbolic play should be embodied within the linguistic approach of Interactive Language Development Teaching devised by Lee et al. ${ }^{14}$ To replace the use of a flannel board, objects such as boxes, sticks etc. can be used. These should be kept out of sight and brought into the child's focus only when mentioned in the story, to prevent excessive hyperactivity. Abstract uses for these objects in relation to the ongoing narrative should be suggested and the child should be encouraged to discover additional symbolic applications. As the story is related and the child asked to respond to the clinician's utterances, so he must simultaneously utilize the objects to create the scene. For example, if the theme is a fishing trip, a cup could be a container for worms, pieces of paper could be worms, and so on.

In this approach, the child can actively interact with is environment, an important consideration in intellectual growth. $4,11,27,29$ $\mathrm{He}$ is encouraged to explore his surroundings and to discover things for himself. The child who is hyperactive can draw the scene as it is related rather than acting it out or reproducing it in miniature.

The flexibility of this method allows for other approaches to be incorporated within it. An example is the 'forced alternative' questioning put forward in the remediation technique of Crystal et al. ${ }^{6}$ This can be used together with a story devised by Lee et al; $^{14}$ a story made up by either the clinician or the child; as well as a symbolic sequence enacted or drawn. Particular emphasis can be placed on that area (syntactic, semantic, categorical, etc.) most delayed for the child. In addition, most of these play activities can be carried out in groups which allows for socialization, interaction and co-operation, parallel play and imitation, all of importance for both linguistic and cognitive development.

In conclusion, future research should be geared towards normative studies in this field which may highlight theoretical controversies, and towards evaluating therapy programmes which have a representational basis comprising' both language and symbolic play.

\section{REFERENCES}

1. Bass, K., Brown, J. B. \& Redmond, A. P. (1975): Symbolic Play in Normal and Language-Impaired Children. Unpublished Master of Science Dissertation, Department of Speech Pathology and Audiology, Emerson College, Canada. 
2. Bloom, L. (1970): Language Development: Form and Function in Emerging Grammars. M.I.T. Press, Massachusetts.

3. Bowerman, M. F. (1974): Discussion Summary - Development of Concepts Underlying Language. Chap. 7 in Language Perspectives - Acquisition, Retardation and Intervention, Schieffelbusch, R. L. and Lloyd, L. L. (Eds.), University Park Press, U.S.A.

4. Bricker, W. A. \& Bricker, D. S. (1974): An Early Language Training Strategy. Chap. 17 in Language Perspectives - Acquisition, Retardation and Interaction, Schieffelbusch, R. L. and Lloyd, L. L. (Eds.), University Park Press, U.S.A.

5. Chomsky, N. (1975): Aspects of the Theory of Syntax. M.I.T. Press, Massachusetts.

6. Crystal, D., Fletcher, P. \& Garman, M. (1976): The Grammatical Analysis of Language Disability. Edward Arnold Publishers, London.

7. El'Konin, D. (1971): Symbolics and its Functions in the Play of Children. Chap. 14 in Child's Play, Herron, W. E. and Sutton-Smith, B., (Eds.), John Wiley and Sons, Inc., New York.

8. Freyberg, J. (1973): Increasing the Imaginative Play of Urban Disadvantaged Kindergarten Children Through Systematic Training. Chap. 6 in The Child's World of Make-Believe - Experimental Studies of Imaginative Play, Singer, J. L., (Ed.), Academic Press, Inc., New York.

9. Furth, H. G. (1966): Thinking Without Language: Psychological Implications of Deafness. The Free Press, New York.

10. Furth, H. G. (1975): On the Nature of Language from the Perspective of Research with Profoundly Deaf Children. Annals of the New York Academy of Science, 263, 70-75.

11. Furth, H. G. \& Wachs, H. (1974): Thinking Goes to School: Piaget's Theory in Practice. Oxford University Press, Inc., U.S.A.

12. Hulme, J. \& Lunzer, E. A. (1966): Play, Language and Reasoning in Subnormal Children. J. Child Psychol. Psychiat., 7, 107-123.

13. Lee, L. L. (1974): Developmental Sentence Analysis. NorthWestern University Press. Evanston, Illinois.

14. Lee, L. L., Koenigsknecht, R. A. \& Mulhern, S. (1975): Interactive Language Development Teaching: The Clinical Presentation of Grammatical Structure. Northwestern University Press, Evanston, Illinois.

15. Lovell, K., Hoyle, H. W. \& Siddall, M. Q. A Study of Some Aspects of the Play and Language of Young Children with Delayed Speech. J. Child Psychol. Psychiat., 9, 41-50.

16. Lowenfeld, M. (1939): The World Pictures of Children. British Journal of Medical Psychology, 18, 65-101.

17. Lunzer, E. A. (1959): Intellectual Development in the Play of Young Children. Educational Review, 11, 205-217. 
18. Luria, A. R. \& Yudovich, F. 1a. ${ }^{-}$(1959): Speech and Development of Mental Processes in the Child. Penguin Books, Ltd., England.

19. Moerk, E. L. (1977): Pragmatic and Semantic Aspects of Early Language Development. University Park Press, U.S.A.

20. Moore, T. E. \& Harris, A. E. (1978): Learing and Thought in Piagetian Theory. Chap. 6 in Alternatives to Piaget: Critical Essays on the Theory, Siegal, L. S. and Brainard, C. J., (Eds.), Academic Press, New York.

21. Morehead, D. M. (1972): Early Grammatical and Semantic Relations: Some Implications for a General Representational Deficit in Linguistically Deviant Children. In Papers and Reports on Child Language Development, Ingram, D., (Ed.), Stanford University, Stanford.

22. Morehead, D. M. \& Ingram, D. (1973): The Development of Base Syntax in Normal and Linguistically-Deviant Children. $J$. Speech Hearing Res., 16, 330-344.

23. Phillips, J. L. (1969): The Origins of Intellect: Piaget's Theory. W. H. Freeman and Co., San Francisco.

24. Piaget, J. (1951): Play, Dreams and Imitation in Childhood. Heinemann, London.

25. Piaget, J. (1966): Response to Brian Sutton-Smith. Chap. 22 in Child's Play, Herron, R. and Sutton-Smith, B. (Eds.), John Wiley and Sons, Inc., New York, 1971.

26. Piaget, J. (1967): Six Psychological Studies. University of London Press, London.

27. Piaget, J. (1971): The Construction of Reality in the Child. Ballantine Books, Inc., New York.

28. Piaget, J. \& Inhelder, B. (1969): The Psychology of the Child. Routledge and Kegan Paul, London.

29. Riley, S. S. (1973): Some Reffections on the Value of Children's Play. Young Children, 146-153.

30. Rubin, K. H. \& Maioni, T. L. (1975): Play Preference and its Relationship to Egocentrism, Popularity and Classification Skills in Pre-Schoolers. Merrill-Palmer Quarterly, 21, 3, 171-179.

31. Sinclair, H. (1970): The Transition from Sensori-Motor Behaviour to Symbolic Activity. Interchange, 1, 3, 119-126.

32. Sinclair-de-Zwart, H. (1972): A Possible Theory of Ĺanguage Acquisition Within the General Framework of Piaget's Developmental Theory. Chap. 19 in Language in Thinking, Adams, P., (Ed.), Penguin Books, Ltd., Engländ.

33. Singer, J. L. (1973): The Child's World of Make-Believe Experimental Studies of Imaginative Play. Academic Press, Inc., New York.

34. Strauss, A. A. \& Kephart, N. C! (1955): Psychopathology and Education of the Brain-Injured Child. Vol. II. Grune and Stratton, New York. 
Verbal Language and Symbolic Play

35. Strauss, A. A. \& Lehtinen, L. (1950): Psychopathology and Education of the Brain-Injured Child. Grune and Stratton, N.Y.

36. Werner, H. \& Kaplan, B. (1963): Symbol Formation: An Organismic-Developmental Approach to Language and the Expansion of Thought. John Wiley and Sons, Inc., N.Y. 


\section{PIII \\ PHOTOGRAPHIC TEAGHING MATERIALS}

\section{Visual Aids for use in Language Development}

CATALOGUE AND PRICE LIST AVAILABLE FROM:

P.T.M.,

23, Horn Steet,

Winslow,

Buckingham.

MK18 3AP. ENGLAND.

Tel: WINSLOW (029 671) 3776. 


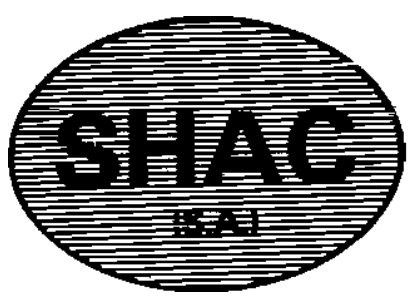

\section{SOCIETY OF HEARING AID CONSULTANTS (S.A.)}

THE SOCIETY OF HEARING AID CONSULTANTS (SA.) IS A GROUP OF CONCERNED HEARING AID SUPPLIERS DEDICATED TO IMPROVING AND MAINTAINING STANDARDS OF HEARING AID DISPENSING.

OUR MEMBERS HAVE FREELY COMMITTED THEMSELVES TO ABIDE BY THE RULES AND DISCIPLINES OF THE SOCIETY IN THE INTERESTS OF PROMOTING THE HIGHEST STANDARDS OF CONDUCT AND COMPETENCE.

SPECIAL MEMBERSHIP IS AVAILABLE TO INTERESTED PERSONS IN ALLIED FIELDS.

ENQUIRIES:

THE SECRETARY, SOCIETY OF HEARING AID CONSULTANTS (SA), PO BOX 4581

JOHANNESBURG 2000

TEL: 23-5791 